\title{
Salinity and Alkaline pH in Irrigation Water Affect Marigold Plants: II. Mineral Ion Relations
}

\author{
Luis A. Valdez-Aguilar ${ }^{1,2}$, Catherine M. Grieve, James Poss, \\ and Donald A. Layfield \\ U.S. Department of Agriculture, Agricultural Research Service, U.S. Salinity \\ Laboratory, 450 West Big Springs Road, Riverside, CA 92507
}

Additional index words. alkalinity, bedding plants, electrical conductivity, Imperial and Coachella Valley, sodium exclusion

\begin{abstract}
Scarcity of good-quality water for landscape irrigation is a major concern in arid and semiarid regions as a result of the competition with the urban population. Competing claims from urban, agricultural, environmental, and industrial groups leaves less water or water of lower quality for use in landscape maintenance. Although degraded waters, high in both salinity and alkaline $\mathrm{pH}$, may challenge plant establishment and growth, these waters must be considered as valuable alternatives to the use of fresh water resources for landscape sites. The objective of the present study was to determine the effect of irrigation with saline water, with and without $\mathrm{pH}$ control, on the mineral ion relations of three marigold cultivars: Flagstaff, Yellow Climax, and French Vanilla. Treatments were five electrical conductivities of irrigation water $\left(\mathrm{EC}_{\mathrm{w}}\right): 2,4,6,8$, and $10 \mathrm{dS} \cdot \mathrm{m}^{-1}$, and two $\mathrm{pH}$ levels: 6.4 and 7.8. Plants of 'French Vanilla' and flowering stems of 'Flagstaff' and 'Yellow Climax' were harvested at flower maturity. Leaves of the taller cultivars, Flagstaff and Yellow Climax, were collected separately from the main axis and from the lateral stems, whereas in 'French Vanilla', leaves were combined. Total sulfur, total phosphorus, $\mathrm{Ca}^{2+}, \mathrm{Mg}^{2+}, \mathrm{Na}^{+}, \mathrm{K}^{+}, \mathrm{Cl}^{-}, \mathrm{Fe}^{2+}, \mathrm{Zn}^{2+}, \mathrm{Cu}^{2+}$, and $\mathrm{Mn}^{2+}$ concentrations in leaf and stem tissues were determined. The three marigold cultivars were strong $\mathrm{Ca}^{2+}-$ accumulators and this response was more evident at the lower $\mathrm{pH}$ level. However, leaf $\mathrm{Ca}^{2+}$ tended to decrease as salinity increased despite a threefold increase in substrate $\mathrm{Ca}^{2+}$. Leaf $\mathrm{Mg}^{2+}$ increased as salinity increased and main stem leaves of the taller cultivars accumulated more $\mathrm{Mg}^{2+}$ than leaves on the lateral branches. The reverse was true for leaf $\mathrm{K}^{+}$; leaves on the lateral branches were stronger $\mathrm{K}^{+}$-accumulators than those on the main stem. Potassium concentrations in leaves of marigold irrigated with waters at $\mathrm{pH} 6.4$ tended to decrease as $\mathrm{EC}_{\mathrm{w}}$ increased. Marigold seems to possess an efficient $\mathrm{Na}^{+}$exclusion mechanism, which restricts $\mathrm{Na}^{+}$accumulation in the leaves. Patterns of total phosphorus accumulation in leaf tissues were not consistent over the range of $\mathbf{E C}_{\mathrm{w}}$ treatments. Among the micronutrients, $\mathrm{Fe}^{2+}$ and $\mathrm{Mn}^{2+}$ tended to be partitioned to the younger rather than the older leaves. The decrease in marigold growth was associated with nutrient ion imbalance as demonstrated by the reduction in $\mathrm{K}^{+}$concentration and the increase in $\mathrm{Mg}^{2+}$ and $\mathrm{Cl}^{-}$in leaf tissue. Despite the reduction in growth, the aesthetic value of the cultivars was not detrimentally affected by application of saline waters with $\mathbf{E C}_{\mathrm{w}}$ values as high as $8 \mathrm{dS} \cdot \mathrm{m}^{-1}$.
\end{abstract}

Water availability and quality are issues of major concern in reference to irrigation of urban landscapes resulting from the competition with a rapidly growing population that requires vast volumes of good-quality water (Kjelgren et al., 2000). Landscape irrigation accounts for $10 \%$ of total volume in the summer rainfall region of the United States,

Received for publication 17 Apr. 2009. Accepted for publication 21 July 2009.

Mention of company names or products is for the benefit of the reader and does not imply endorsements, guarantee, or preferential treatment by the USDA or its agents.

${ }^{1}$ Current affiliation: Centro de Investigación en Química Aplicada, Blvd. Enrique Reyna Hermosillo 140, Saltillo, Coah, 25253 México.

${ }^{2}$ To whom reprint requests should be addressed; e-mail lavaldez@ciqa.mx.
'French Vanilla' (Tagetes patula) and 'Flagstaff' and 'Yellow Climax' (both T. erecta). The results showed that marigold is sensitive to electrical conductivity of irrigation water $\left(\mathrm{EC}_{\mathrm{w}}\right)$ higher than $4 \mathrm{dS} \cdot \mathrm{m}^{-1}$ and that growth reduction was greater when $\mathrm{pH}$ of irrigation water was 7.8 compared with 6.4. However, despite the growth reduction resulting from increasing salinity, plants were still of acceptable quality for landscape use even when $\mathrm{EC}_{\mathrm{w}}$ was as high as $8 \mathrm{dS} \cdot \mathrm{m}^{-1}$. High irrigation water $\mathrm{pH}$, however, caused a significant loss of aesthetic value. The objective of the present study was to investigate the relationship between the growth reduction detected in marigold as an effect of irrigation with saline water and high $\mathrm{pH}$ and ion accumulation to understand potential ion imbalances.

\section{Materials and Methods}

The experiment was conducted in a greenhouse at the U.S. Salinity Laboratory in Riverside, CA. Growth conditions and additional experimental details are provided in the companion paper (Valdez-Aguilar et al., 2009b). Three marigold cultivars, French Vanilla, Yellow Climax, and Flagstaff, were used for the present study. Treatments consisted of five $\mathrm{EC}_{\mathrm{w}}$ simulating the ionic composition of Colorado River water (Table 1) and were based on predictions of what longterm compositions would be on further concentration resulting from plant water extraction and evaporation (Suarez and Simunek, 1997). The $\mathrm{EC}_{\mathrm{w}}$ treatments were 2, 4, 6, 8, and 10 $\mathrm{dS} \cdot \mathrm{m}^{-1}$ and two $\mathrm{pH}$ levels: $6.4( \pm 0.1)$ and 7.8 $( \pm 0.2)$. Irrigation water was acidified by adding $\mathrm{HNO}_{3}$ until the target nitrogen concentration was reached and thereafter with $\mathrm{H}_{2} \mathrm{SO}_{4}$. Nutrient concentration of the irrigation solutions was maintained constant and was prepared as described in a companion paper (Valdez-Aguilar et al., 2009b). The higher $\mathrm{pH}$ was the normal $\mathrm{pH}$ of Riverside tap water. At harvest, average alkalinity was $0.47 \pm 0.05$ and $1.82 \pm 0.09 \mathrm{meq} \cdot \mathrm{L}^{-1}$ (mean \pm $\mathrm{SE}, \mathrm{n}=5$ ) for solutions with $\mathrm{pH} 6.4$ and 7.8 , respectively.

Plants were irrigated twice daily for sufficient duration to completely saturate the sand. Solutions then drained to reservoirs below the tanks for reuse in the next irrigation. Calculations, accounting for maximum evapotranspiration, soil waterholding capacity, and intervals between irrigations, indicate that the salinity of the irrigation water $\left(\mathrm{EC}_{\mathrm{w}}\right)$ was essentially equivalent to the salinity of the sand water $\left(\mathrm{EC}_{\mathrm{sw}}\right)$. Based on a study of the soil-water dynamics in this river sand (Wang, 2002), $\mathrm{EC}_{\mathrm{sw}}$ is $\approx 2.2$ times the $\mathrm{EC}$ of the saturated soil extract $\left(\mathrm{EC}_{\mathrm{e}}\right)$, the salinity parameter used to characterize salt tolerance in most studies (Ayers and Westcot, 1985). Our salinity treatments may be estimated as $0.91,1.82 .2 .73,3.64$, and $4.55 \mathrm{dS} \cdot \mathrm{m}^{-1}$. Thus, the threshold $\mathrm{EC}_{\mathrm{w}}$ at which marigold cultivars exhibited acceptable growth, $8 \mathrm{dS} \cdot \mathrm{m}^{-1}$, would be equivalent to an $\mathrm{EC}_{\mathrm{e}}$ of $3.64 \mathrm{dS} \cdot \mathrm{m}^{-1}$ (Valdez-Aguilar et al., 2009b). 
Table 1. Composition of salinizing salts in solutions used to irrigate marigold grown in greenhouse sand tanks.

\begin{tabular}{lrrrrr}
\hline $\mathrm{EC}_{\mathrm{w}}$ & \multicolumn{5}{c}{ Concn (meq. $\left.\mathrm{L}^{-1}\right)$} \\
\cline { 2 - 6 }$\left(\mathrm{dS} \cdot \mathrm{m}^{-1}\right)$ & $\mathrm{Ca}^{2+}$ & $\mathrm{Mg}^{2+}$ & \multicolumn{1}{c}{$\mathrm{Na}^{+}$} & $\mathrm{SO}_{4}^{2-}$ & $\mathrm{Cl}^{-}$ \\
\hline 2 & 5.0 & 5.0 & 8.0 & 5.0 & 13.0 \\
4 & 7.8 & 12.1 & 20.9 & 13.1 & 27.5 \\
6 & 11.4 & 18.7 & 32.3 & 20.0 & 42.0 \\
8 & 15.1 & 25.3 & 43.6 & 27.2 & 57.2 \\
10 & 18.8 & 32.6 & 55.0 & 34.6 & 72.5 \\
\hline $\mathrm{EC}_{\mathrm{w}}=$ electrical conductivity of water.
\end{tabular}

$\mathrm{EC}_{\mathrm{w}}=$ electrical conductivity of water.

Plants were harvested when most of the flower heads were fully mature. Leaf samples from the main shoot (LMS) and from the lateral shoots (LLS) of 'Flagstaff' and 'Yellow Climax' were separated from the stems, whereas samples of 'French Vanilla' included both leaves from the main shoot plus from the lateral shoots. Leaves and stems were washed twice in deionized water, blotted dry, placed in paper bags, and oven-dried at $70{ }^{\circ} \mathrm{C}$ for $5 \mathrm{~d}$. Once dried, the plant samples were ground to pass a 20-mesh screen. Total sulfur, total phosphorus, $\mathrm{Ca}^{2+}, \mathrm{Mg}^{2+}, \mathrm{Na}^{+}, \mathrm{K}^{+}, \mathrm{Fe}^{2+}, \mathrm{Zn}^{2+}$, $\mathrm{Cu}^{2+}$, and $\mathrm{Mn}^{2+}$ were analyzed on nitricperchloric acid digests of the leaf and the stem tissues by inductively coupled plasma optical emission spectrometry. Chloride was analyzed on nitric-acetic acid extracts by coulometric-amperometric titration. The study was designed as a factorial experiment and set as a completely randomized design. Collected data and linear, quadratic, and cubic trends were analyzed by the analysis of variance procedure using SAS Version 8.2 (SAS Institute, Inc., 2001).

\section{Results and Discussion}

Calcium. Increasing $\mathrm{EC}_{\mathrm{w}}$ and alkaline $\mathrm{pH}$ of irrigation water caused a general decrease in leaf $\mathrm{Ca}^{2+}$ concentration (Fig. 1). In the LLS of 'Flagstaff' and 'Yellow Climax', $\mathrm{Ca}^{2+}$ concentration was significantly affected by the $\mathrm{pH}$ of the irrigation water, but not by the $\mathrm{pH} \times \mathrm{EC}_{\mathrm{w}}$ interaction, whereas in the LMS, there was a significant $\mathrm{pH} \times \mathrm{EC}_{\mathrm{w}}$ interaction in both cultivars (Tables 2 and 3 ). The interaction in LMS was the result of the strong effect of $\mathrm{pH}$ resulting in higher $\mathrm{Ca}^{2+}$ concentrations when the substrate was acidic and $\mathrm{EC}_{\mathrm{w}}$ was lower than $6 \mathrm{dS} \cdot \mathrm{m}^{-1}$. Increasing $\mathrm{EC}_{\mathrm{w}}$ resulted in a significant decrease of $\mathrm{Ca}^{2+}$ in 'French Vanilla' (Table 4) and a significant interaction resulting from the lack of response as $\mathrm{EC}_{\mathrm{w}}$ increased up to $6 \mathrm{dS} \cdot \mathrm{m}^{-1}$ when $\mathrm{pH}$ was $6.4 ; \mathrm{Ca}^{2+}$ decreased in a quadratic fashion in this cultivar when $\mathrm{pH}$ was 7.8 (Table 4; Fig. 1).

Main shoot leaves of 'Flagstaff' and 'Yellow Climax' accumulated higher $\mathrm{Ca}^{2+}$ at pH 6.4 compared with the LLS (Fig. 1). However, $\mathrm{Ca}^{2+}$ concentration was significantly reduced when $\mathrm{EC}_{\mathrm{w}}$ rose to 8 or 10 $\mathrm{dS} \cdot \mathrm{m}^{-1}$. The decrease in $\mathrm{Ca}^{2+}$ uptake may be the result of external ionic interactions with high salinity or the displacement of $\mathrm{Ca}^{2+}$ in the plasma membrane of root cells at high $\mathrm{Na}^{+}$ concentration (Cramer et al., 1985). Reduced plant growth of the three marigold cultivars was observed even at $\mathrm{EC}_{\mathrm{w}}$ of 4 and $6 \mathrm{dS} \cdot \mathrm{m}^{-1}$, as reported in the companion paper (ValdezAguilar et al., 2009b); this response may be related to the osmotic effect of increasing salinity because a decrease in $\mathrm{Ca}^{2+}$ concentration was not detected at these $\mathrm{EC}_{\mathrm{w}}$ levels. In addition, leaf dry weight (DW) production was significantly correlated with leaf $\mathrm{Ca}^{2+}$ content in all the three marigold cultivars (Table 5), suggesting that leaf $\mathrm{Ca}^{2+}$ accumulation was being regulated by growth.

Contrasting results concerning the effect of $\mathrm{pH}$ on $\mathrm{Ca}^{2+}$ accumulation have been

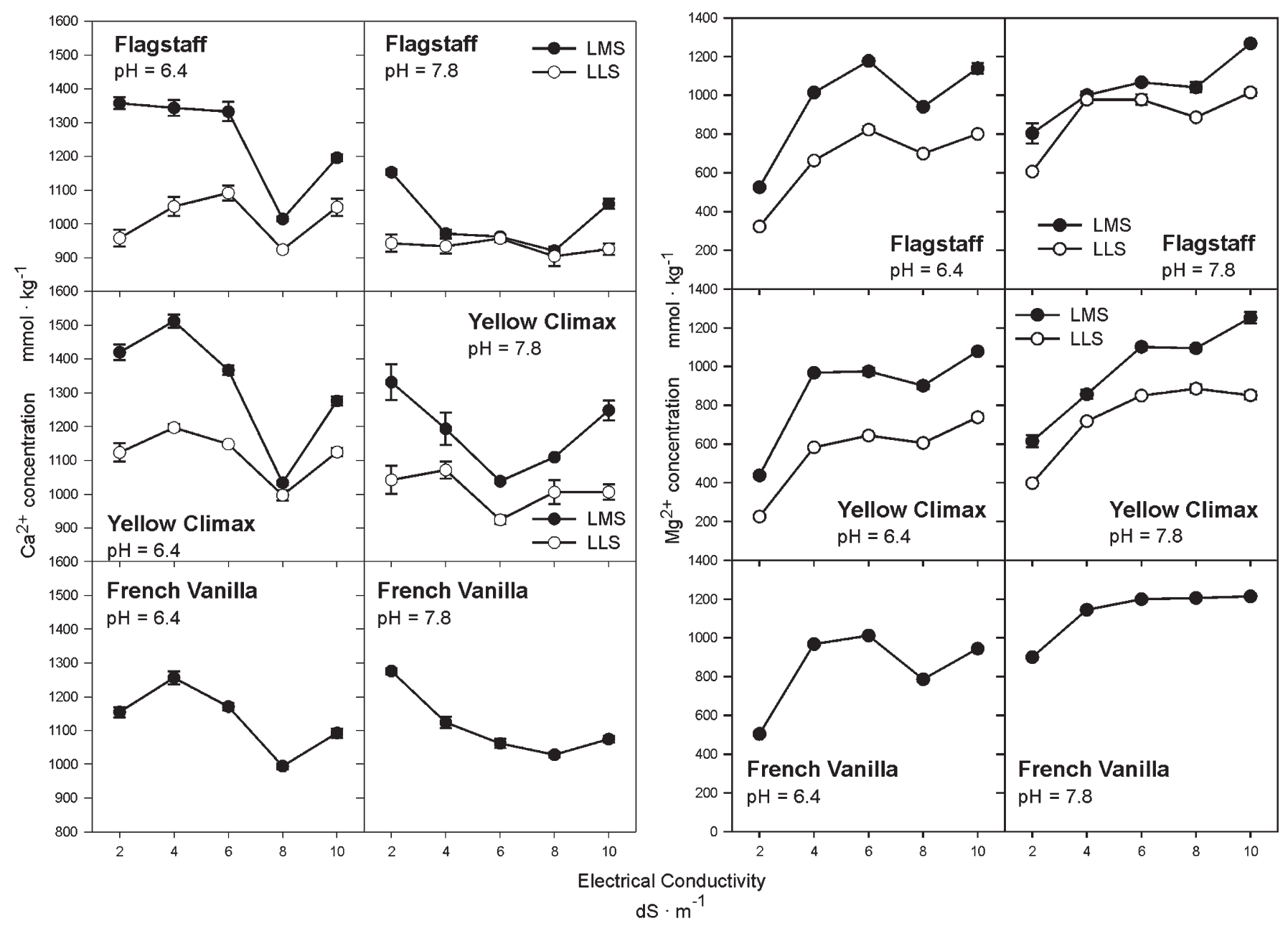

Fig. 1. Calcium and magnesium concentration in leaves of marigold Tagetes patula 'French Vanilla' or in leaves from the main shoot (LMS) and from the lateral shoots (LLS) in Tagetes erecta 'Flagstaff' and 'Yellow Climax' irrigated with water with increasing electrical conductivity and two pH levels. For some measurements, SE was smaller than the data point. Values are the means of three observations \pm SE. 
Table 2. Significance of trends and the effect of electrical conductivity of irrigation water $\left(\mathrm{EC}_{\mathrm{w}}\right), \mathrm{pH}$, and $\mathrm{pH} \times \mathrm{EC}_{\mathrm{w}}$ interaction on ion concentration in leaves from the main shoot (LMS) and lateral shoots (LLS) of marigold Tagetes erecta 'Flagstaff'.

\begin{tabular}{|c|c|c|c|c|c|c|c|c|c|c|c|c|c|c|c|c|c|c|c|c|c|c|}
\hline & \multicolumn{2}{|c|}{$\mathrm{Ca}^{2+}$} & \multicolumn{2}{|c|}{$\mathrm{Mg}^{2+}$} & \multicolumn{2}{|c|}{$\mathrm{Na}^{+}$} & \multicolumn{2}{|c|}{$\mathrm{K}^{+}$} & \multicolumn{2}{|c|}{$\begin{array}{c}\text { Total } \\
\text { phosphorus }\end{array}$} & \multicolumn{2}{|c|}{ Total sulfur } & \multicolumn{2}{|c|}{$\mathrm{Cl}^{-}$} & \multicolumn{2}{|c|}{$\mathrm{Fe}^{2+}$} & \multicolumn{2}{|c|}{$\mathrm{Cu}^{2+}$} & \multicolumn{2}{|c|}{$\mathrm{Mn}^{2+}$} & \multicolumn{2}{|c|}{$\mathrm{Zn}^{2+}$} \\
\hline & 6.4 & 7.8 & 6.4 & 7.8 & 6.4 & 7.8 & 6.4 & 7.8 & 6.4 & 7.8 & 6.4 & 7.8 & 6.4 & 7.8 & 6.4 & 7.8 & 6.4 & 7.8 & 6.4 & 7.8 & 6.4 & 7.8 \\
\hline \multicolumn{23}{|c|}{$L L S$} \\
\hline$\overline{\mathrm{L}^{\mathrm{z}, \mathrm{y}}}$ & NS & NS & $* * *$ & $* * *$ & NS & NS & $* * *$ & NS & NS & NS & NS & $*$ & $* * *$ & $* * *$ & NS & NS & $*$ & NS & NS & NS & $* *$ & NS \\
\hline Q & NS & NS & $* * *$ & $* *$ & NS & NS & $* *$ & $*$ & $*$ & NS & NS & NS & $*$ & NS & NS & NS & NS & NS & NS & NS & $* * *$ & NS \\
\hline $\mathrm{C}$ & $*$ & NS & $* * *$ & $* *$ & NS & $* *$ & $* * *$ & NS & $* *$ & $*$ & $* * *$ & $* *$ & NS & NS & NS & NS & NS & $*$ & NS & NS & $* * *$ & NS \\
\hline $\mathrm{EC}_{\mathrm{w}}$ & \multicolumn{2}{|c|}{$\mathrm{NS}^{\mathrm{z}}$} & \multicolumn{2}{|c|}{$* * *$} & \multicolumn{2}{|c|}{ NS } & \multicolumn{2}{|c|}{$* * *$} & & & \multicolumn{2}{|c|}{$* * *$} & \multicolumn{2}{|c|}{$* * *$} & \multicolumn{2}{|c|}{ NS } & \multicolumn{2}{|c|}{$* *$} & \multicolumn{2}{|c|}{ NS } & \multicolumn{2}{|c|}{$* * *$} \\
\hline $\mathrm{pH}$ & \multicolumn{2}{|c|}{$*$} & \multicolumn{2}{|c|}{$* * *$} & \multicolumn{2}{|c|}{ NS } & \multicolumn{2}{|c|}{ NS } & & & \multirow{2}{*}{\multicolumn{2}{|c|}{$*$}} & \multirow{2}{*}{\multicolumn{2}{|c|}{$\begin{array}{l}\text { NS } \\
* * *\end{array}$}} & & & \multirow{2}{*}{\multicolumn{2}{|c|}{$*$}} & & & \multirow{2}{*}{\multicolumn{2}{|c|}{$\begin{array}{l}* * * \\
* * *\end{array}$}} \\
\hline $\operatorname{Int}^{x}$ & & & & & & & & & & & & & & & & & & & & & & \\
\hline & & & & & & & & & & & $L M S$ & & & & & & & & & & & \\
\hline$\overline{\mathrm{L}^{z y}}$ & $* * *$ & $* *$ & $* * *$ & $* * *$ & NS & NS & $* * *$ & NS & NS & NS & NS & $* *$ & $* * *$ & $* * *$ & NS & NS & $*$ & * & NS & NS & NS & $*$ \\
\hline Q & NS & $* * *$ & $* * *$ & NS & NS & NS & $* *$ & NS & $*$ & NS & NS & NS & $*$ & NS & NS & NS & NS & NS & NS & NS & NS & NS \\
\hline $\mathrm{C}$ & $* *$ & NS & $* * *$ & NS & NS & NS & $* * *$ & $*$ & $* *$ & NS & $*$ & NS & NS & NS & NS & NS & NS & $*$ & NS & NS & $* * *$ & NS \\
\hline $\mathrm{EC}_{\mathrm{w}}$ & & & & & & & & & & & & & & & & & & & & & & \\
\hline $\mathrm{pH}$ & & & & & & & & & & & & & & & & & & & & & & \\
\hline $\operatorname{Int}^{\mathrm{x}}$ & & & & & & & & & & & & & & & & & & & & & & \\
\hline
\end{tabular}

${ }^{\mathrm{z}} \mathrm{L}, \mathrm{Q}, \mathrm{C}=$ lineal, quadratic, and cubic trends, respectively.

${ }_{\mathrm{NS}}, * * *, * * *=$ Nonsignificant and significant at $P<0.05, P<0.01$, and $P<0.001$, respectively.

${ }^{\mathrm{x}}$ Interaction $\mathrm{pH} \times \mathrm{EC}_{\mathrm{w}}$.

Table 3. Significance of trends and the effect of electrical conductivity of irrigation water $\left(\mathrm{EC}_{\mathrm{w}}\right), \mathrm{pH}$, and $\mathrm{pH} \times \mathrm{EC}_{\mathrm{w}}$ interaction on ion concentration in leaves from the main shoot (LMS) and lateral shoots (LLS) of marigold Tagetes erecta 'Yellow Climax'.

\begin{tabular}{|c|c|c|c|c|c|c|c|c|c|c|c|c|c|c|c|c|c|c|c|c|c|c|}
\hline & \multicolumn{2}{|c|}{$\mathrm{Ca}^{2+}$} & \multicolumn{2}{|c|}{$\mathrm{Mg}^{2+}$} & \multicolumn{2}{|c|}{$\mathrm{Na}^{+}$} & \multicolumn{2}{|c|}{$\mathrm{K}^{+}$} & \multicolumn{2}{|c|}{$\begin{array}{c}\text { Total } \\
\text { phosphorus }\end{array}$} & \multicolumn{2}{|c|}{ Total sulfur } & \multicolumn{2}{|c|}{$\mathrm{Cl}^{-}$} & \multicolumn{2}{|c|}{$\mathrm{Fe}^{2+}$} & \multicolumn{2}{|c|}{$\mathrm{Cu}^{2+}$} & \multicolumn{2}{|c|}{$\mathrm{Mn}^{2+}$} & \multicolumn{2}{|c|}{$\mathrm{Zn}^{2+}$} \\
\hline & 6.4 & 7.8 & 6.4 & 7.8 & 6.4 & 7.8 & 6.4 & 7.8 & 6.4 & 7.8 & 6.4 & 7.8 & 6.4 & 7.8 & 6.4 & 7.8 & 6.4 & 7.8 & 6.4 & 7.8 & 6.4 & 7.8 \\
\hline \multicolumn{23}{|c|}{$L L S$} \\
\hline$\overline{\mathrm{L}^{\mathrm{z}, \mathrm{y}}}$ & NS & NS & $* * *$ & NS & NS & NS & $* * *$ & NS & NS & NS & $*$ & $*$ & $* * *$ & $* * *$ & NS & NS & NS & NS & $* *$ & NS & NS & NS \\
\hline Q & NS & NS & $* * *$ & $* * *$ & NS & NS & $* *$ & NS & NS & NS & NS & NS & NS & $* * *$ & NS & NS & $*$ & NS & NS & NS & $*$ & NS \\
\hline $\mathrm{C}$ & $* *$ & NS & $* * *$ & $* * *$ & NS & $* *$ & $* * *$ & NS & $*$ & NS & $* * *$ & NS & NS & $*$ & NS & NS & NS & $*$ & NS & NS & $*$ & NS \\
\hline $\mathrm{EC}_{\mathrm{w}}$ & \multicolumn{2}{|c|}{ NS } & \multicolumn{2}{|c|}{$* * *$} & \multicolumn{2}{|c|}{ NS } & \multicolumn{2}{|c|}{$* * *$} & \multicolumn{2}{|c|}{$*$} & \multicolumn{2}{|c|}{$* *$} & \multicolumn{2}{|c|}{$* * *$} & \multicolumn{2}{|c|}{ NS } & \multicolumn{2}{|c|}{$*$} & \multicolumn{2}{|c|}{ NS } & \multicolumn{2}{|c|}{ NS } \\
\hline $\mathrm{pH}$ & \multicolumn{2}{|c|}{$* *$} & \multicolumn{2}{|c|}{$* * *$} & \multicolumn{2}{|c|}{ NS } & \multicolumn{2}{|c|}{ NS } & \multicolumn{2}{|c|}{$* * *$} & \multicolumn{2}{|c|}{ NS } & \multicolumn{2}{|c|}{$* *$} & & & & & & & & \\
\hline $\operatorname{Int}^{\mathrm{x}}$ & & & & & & & & & & & & & & & & & & & & & & \\
\hline & & & & & & & & & & & $L M S$ & & & & & & & & & & & \\
\hline$\overline{\mathrm{L}^{z y}}$ & $* * *$ & NS & $* * *$ & $* * *$ & NS & NS & $* * *$ & NS & NS & $*$ & $* * *$ & $* *$ & $* * *$ & $* * *$ & NS & NS & NS & NS & $* *$ & NS & NS & NS \\
\hline Q & NS & $*$ & $* * *$ & $*$ & NS & $*$ & $* * *$ & $*$ & $*$ & NS & NS & NS & $*$ & $*$ & $*$ & $* *$ & NS & NS & NS & NS & NS & NS \\
\hline C & $* * *$ & NS & $* * *$ & NS & NS & NS & $* * *$ & NS & $* *$ & NS & $*$ & NS & NS & $*$ & NS & NS & NS & NS & NS & NS & NS & NS \\
\hline $\mathrm{EC}_{\mathrm{w}}$ & & & & & & & & & & & & & & & & & & & & & & \\
\hline $\mathrm{pH}$ & & & & & & & & & & & & & & & & & & & & & & \\
\hline $\operatorname{Int}^{\mathrm{x}}$ & & & & & & & & & & & & & & & & & & & & & & \\
\hline
\end{tabular}

${ }^{\mathrm{z}} \mathrm{L}, \mathrm{Q}, \mathrm{C}=$ lineal, quadratic, and cubic trends, respectively.

${ }^{\mathrm{N} S}, * * *, * * *=$ Nonsignificant and significant at $P<0.05, P<0.01$, and $P<0.001$, respectively.

${ }^{\mathrm{x}}$ Interaction $\mathrm{pH} \times \mathrm{EC}_{\mathrm{w}}$.

Table 4. Significance of trends and the effect of electrical conductivity of irrigation water $\left(\mathrm{EC}_{\mathrm{w}}\right), \mathrm{pH}$, and $\mathrm{pH} \times \mathrm{EC}_{\mathrm{w}}$ interaction on ion concentration in leaves of marigold Tagetes patula 'French Vanilla'.

\begin{tabular}{|c|c|c|c|c|c|c|c|c|c|c|c|c|c|c|c|c|c|c|c|c|c|c|}
\hline & \multicolumn{2}{|c|}{$\mathrm{Ca}^{2+}$} & \multicolumn{2}{|c|}{$\mathrm{Mg}^{2+}$} & \multicolumn{2}{|c|}{$\mathrm{Na}^{+}$} & \multicolumn{2}{|c|}{$\mathrm{K}^{+}$} & \multicolumn{2}{|c|}{ Total phosphorus } & \multicolumn{2}{|c|}{ Total sulfur } & \multicolumn{2}{|c|}{$\mathrm{Cl}^{-}$} & \multicolumn{2}{|c|}{$\mathrm{Fe}^{2+}$} & \multicolumn{2}{|c|}{$\mathrm{Cu}^{2+}$} & \multicolumn{2}{|c|}{$\mathrm{Mn}^{2+}$} & \multicolumn{2}{|c|}{$\mathrm{Zn}^{2+}$} \\
\hline & 6.4 & 7.8 & 6.4 & 7.8 & 6.4 & 7.8 & 6.4 & 7.8 & 6.4 & 7.8 & 6.4 & 7.8 & 6.4 & 7.8 & 6.4 & 7.8 & 6.4 & 7.8 & 6.4 & 7.8 & 6.4 & 7.8 \\
\hline$\overline{\mathrm{L}^{z y}}$ & $* * *$ & $* * *$ & $* * *$ & $* * *$ & $*$ & NS & $* *$ & $*$ & NS & $*$ & $*$ & $* * *$ & $* * *$ & $* * *$ & NS & NS & NS & $* * *$ & NS & NS & NS & NS \\
\hline Q & NS & $* * *$ & $* * *$ & $* * *$ & NS & NS & $*$ & NS & $* * *$ & $* *$ & $* *$ & NS & $* *$ & $* *$ & NS & $*$ & NS & NS & NS & NS & NS & NS \\
\hline $\mathrm{C}$ & $* * *$ & NS & $* * *$ & $*$ & $*$ & NS & $* * *$ & NS & $* * *$ & NS & $* *$ & $*$ & NS & NS & NS & NS & NS & NS & NS & NS & $* *$ & NS \\
\hline $\mathrm{EC}_{\mathrm{w}}$ & \multicolumn{2}{|c|}{$* * *$} & \multicolumn{2}{|c|}{$* * *$} & \multicolumn{2}{|c|}{ NS } & \multicolumn{2}{|c|}{$* * *$} & \multicolumn{2}{|c|}{$* * *$} & \multicolumn{2}{|c|}{$* * *$} & \multicolumn{2}{|c|}{$* * *$} & \multicolumn{2}{|c|}{ NS } & \multicolumn{2}{|c|}{ NS } & \multicolumn{2}{|c|}{ NS } & \multicolumn{2}{|c|}{$* *$} \\
\hline $\mathrm{pH}$ & \multicolumn{2}{|c|}{ NS } & \multicolumn{2}{|c|}{$* * *$} & \multicolumn{2}{|c|}{$*$} & \multicolumn{2}{|c|}{$* * *$} & \multicolumn{2}{|c|}{$\begin{array}{l}* * * \\
* * *\end{array}$} & \multirow{2}{*}{\multicolumn{2}{|c|}{$\begin{array}{l}\mathrm{NS} \\
* * *\end{array}$}} & \multicolumn{2}{|c|}{$* *$} & \multicolumn{2}{|c|}{ NS } & \multicolumn{2}{|c|}{$* * *$} & \multicolumn{2}{|c|}{$* * *$} & \multicolumn{2}{|c|}{$* * *$} \\
\hline $\operatorname{Int}^{x}$ & \multicolumn{2}{|c|}{$* * *$} & & & & & & & & & & & & & & & & & & & & * \\
\hline
\end{tabular}

${ }^{\mathrm{z}} \mathrm{L}, \mathrm{Q}, \mathrm{C}=$ lineal, quadratic, and cubic trends, respectively.

${ }_{\mathrm{NS}}, *, * * * * *=$ Nonsignificant and significant at $P<0.05, P<0.01$, and $P<0.001$, respectively.

${ }^{\mathrm{x}}$ Interaction $\mathrm{pH} \times \mathrm{EC}_{\mathrm{w}}$.

reported. In the present experiment, $\mathrm{Ca}^{2+}$ concentration decreased only when $\mathrm{EC}_{\mathrm{w}}$ was $8 \mathrm{dS} \cdot \mathrm{m}^{-1}$ or higher, but in the LLS of 'Flagstaff' and 'Yellow Climax', $\mathrm{Ca}^{2+}$ concentration was unaffected compared with control plants (Fig. 1). When plants were irrigated with water of alkaline $\mathrm{pH}, \mathrm{Ca}^{2+}$ concentration decreased when $\mathrm{EC}_{\mathrm{w}}$ was 2 to $6 \mathrm{dS} \cdot \mathrm{m}^{-1}$ in 'Flagstaff' and 'Yellow Climax' (or 4 to $6 \mathrm{dS} \cdot \mathrm{m}^{-1}$ in 'French Vanilla'); thus, high $\mathrm{pH}$ stress induced a lower $\mathrm{Ca}^{2+}$ uptake even at lower salinity. This is in contrast to a report presented by Islam et al. (1980), which indicated increased $\mathrm{Ca}^{2+}$ in shoots of several species when $\mathrm{pH}$ was increased up to 8.5. Calcium acquisition may have been suppressed under high salinity as a result of interactions with other ions in the external solution, resulting in lower $\mathrm{Ca}^{2+}$ activity, but the combination of high salinity and high $\mathrm{pH}$ may decrease $\mathrm{Ca}^{2+}$ activity at a greater extent as a result of the formation of calcium carbonates. When plants were exposed to the combination of alkaline $\mathrm{pH}$ and increasing $\mathrm{EC}_{\mathrm{w}}$, the concentration of $\mathrm{Ca}^{2+}$ in the younger leaves was not markedly different from that of plants irrigated with water at $\mathrm{pH} 6.4$.

Magnesium. Magnesium concentration generally increased with increasing $\mathrm{EC}_{\mathrm{w}}$ in all three marigold cultivars (Fig. 1; Tables 2-4). In 
Table 5. Regression models for leaf content of $\mathrm{Ca}^{2+}, \mathrm{K}^{+}$(mmol/plant), micronutrients (mg/plant), and leaf dry weight (Y), in grams, in three cultivars of marigold. ${ }^{\mathrm{z}}$

\begin{tabular}{llcr}
\hline Nutrient content & \multicolumn{1}{c}{ Cultivar } & Model & $R^{2}$ \\
\hline Calcium & Flagstaff & $\mathrm{Y}=-0.331+1.031 \mathrm{Ca}^{2+}$ & 0.981 \\
& Yellow Climax & $\mathrm{Y}=-0.162+0.897 \mathrm{Ca}^{2+}$ & 0.983 \\
Potassium & French Vanilla & $\mathrm{Y}=0.145+0.772 \mathrm{Ca}^{2+}$ & 0.963 \\
& Flagstaff & $\mathrm{Y}=1.576+1.708 \mathrm{~K}^{+}$ & 0.919 \\
& Yellow Climax & $\mathrm{Y}=2.065+2.041 \mathrm{~K}^{+}$ & 0.909 \\
Iron & French Vanilla & $\mathrm{Y}=0.624+1.270 \mathrm{~K}$ & 0.821 \\
& Flagstaff & $\mathrm{Y}=-0.325+5.017 \mathrm{Fe}$ & 0.871 \\
& Yellow Climax & $\mathrm{Y}=0.360+7.757 \mathrm{Fe}$ & 0.931 \\
Zinc & French Vanilla & $\mathrm{Y}=0.029+5.817 \mathrm{Fe}$ & 0.896 \\
& Flagstaff & $\mathrm{Y}=0.879+66.240 \mathrm{Zn}$ & 0.972 \\
& Yellow Climax & $\mathrm{Y}=1.706+45.981 \mathrm{Zn}$ & 0.944 \\
Copper & French Vanilla & $\mathrm{Y}=0.600+32.734 \mathrm{Zn}$ & 0.689 \\
& Flagstaff & $\mathrm{Y}=-0.818+110.7 \mathrm{Cu}$ & 0.960 \\
& Yellow Climax & $\mathrm{Y}=1.461+92.009 \mathrm{Cu}$ & 0.948 \\
Manganese & French Vanilla & $\mathrm{Y}=0.423+79.767 \mathrm{Cu}$ & 0.891 \\
& Flagstaff & $\mathrm{Y}=0.667+4.990 \mathrm{Mn}$ & 0.912 \\
& Yellow Climax & $\mathrm{Y}=0.934+4.673 \mathrm{Mn}$ & 0.874 \\
& French Vanilla & $\mathrm{Y}=0.562+2.382 \mathrm{Mn}$ & 0.691 \\
\hline
\end{tabular}

${ }^{2}$ Ion content considered both leaves from the main stem and form the lateral stems ( $\mathrm{n}=60$ for 'Flagstaff' and 'Yellow Climax'; $\mathrm{n}=30$ for 'French Vanilla').

'Flagstaff' and 'Yellow Climax', $\mathrm{Mg}^{2+}$ concentration was higher in the LMS than in LLS; however, the magnitude of the difference between leaf positions was larger when $\mathrm{EC}_{\mathrm{w}}$ was higher than $4 \mathrm{dS} \cdot \mathrm{m}^{-1}$. The combination of $\mathrm{pH}$ and $\mathrm{EC}_{\mathrm{w}}$ treatments resulted in a significant interaction, which is explained by the different $\mathrm{Mg}^{2+}$ concentration resulting from the $\mathrm{pH}$ effect when plants were irrigated with nonsaline water (Fig. 1). In plants irrigated with acid water, a quadratic trend best described the increased $\mathrm{Mg}^{2+}$ concentration in response to higher $\mathrm{EC}_{\mathrm{w}}$. However, when $\mathrm{pH}$ was 7.8, the response was linear for the LMS and cubic for the LLS (Tables 2-4).

The increase in $\mathrm{Mg}^{2+}$ concentration was probably the result of external $\mathrm{Mg}^{2+}$, increasing in concert with increasing $\mathrm{EC}_{\mathrm{w}}$ (Table 1). It is well established that $\mathrm{Mg}^{2+}$ competes with $\mathrm{Ca}^{2+}$ (Marschner, 1995) by decreasing the membrane sorption capacity even at a higher extent than $\mathrm{Na}^{+}$(Yermiyahu et al., 1994). Because the activity of external $\mathrm{Ca}^{2+}$ may have been decreased at high $\mathrm{EC}_{\mathrm{w}}$, the competition at membrane level between $\mathrm{Ca}^{2+}$ and $\mathrm{Mg}^{2+}$ might have been lower, leading to an increase in the selectivity of $\mathrm{Mg}^{2+}$ over $\mathrm{Ca}^{2+}$. Carvajal et al. (1999) reported that yield in hydroponically grown tomato was negatively correlated with increasing $\mathrm{Mg}^{2+}$ concentration in the external saline solutions, suggesting that the response was the result of nutrient imbalances because there was a clear $\mathrm{Ca}^{2+}: \mathrm{Mg}^{2+}$ interaction. In another study (Carvajal et al., 2000), this nutrient imbalance hypothesis was also supported because growth of tomato plants was partially restored under salinity treatments when the $\mathrm{Ca}^{2+}: \mathrm{K}^{+}: \mathrm{Mg}^{2+}$ ratio of the external solution was more balanced $(10: 12: 3)$ than when it was higher in $\mathrm{Ca}^{2+}$ and $\mathrm{K}^{+}(4: 6: 1)$.

In general, alkaline $\mathrm{pH}$ of irrigation water was associated with an increase in $\mathrm{Mg}^{2+}$ concentration. The tendency to accumulate more leaf $\mathrm{Mg}^{2+}$ in plants irrigated with $2 \mathrm{dS} \cdot \mathrm{m}^{-1}$ alkaline water, rather than under slightly acidic conditions, is in agreement with reports by Islam et al. (1980), who observed this response in the shoots of ginger, cassava, tomato, French bean, wheat, and maize. Increased acquisition of $\mathrm{Mg}^{2+}$ may also be related to the decreased competition with $\mathrm{Ca}^{2+}$ resulting from the formation of calcium carbonates under high $\mathrm{pH}$ and/or a decrease in the efficiency of the $\mathrm{H}^{+}$pump at high $\mathrm{H}^{+}$ concentration in the external medium (Marschner, 1995).

Potassium. In the LMS and LLS of 'Flagstaff' and 'Yellow Climax' as well as in the leaves of 'French Vanilla', concentration of $\mathrm{K}^{+}$decreased when plants were irrigated with $\mathrm{EC}_{\mathrm{w}} 4 \mathrm{dS} \cdot \mathrm{m}^{-1}$ or higher and acidic pH (Fig. 2; Tables 2-4). However, higher $\mathrm{EC}_{\mathrm{w}}$ values did not result in additional reduction in $\mathrm{K}^{+}$concentration, explaining the cubic trends detected when $\mathrm{pH}$ was 6.4 . The decrease in internal $\mathrm{K}^{+}$concentration has been associated with a competition between external $\mathrm{K}^{+}$and high external $\mathrm{Na}^{+}$in saline solutions (Grattan and Grieve, 1999). The interaction of alkaline $\mathrm{pH}$ and increasing $\mathrm{EC}_{\mathrm{w}}$ was explained principally by the decrease in tissue $\mathrm{K}^{+}$concentration when $\mathrm{EC}_{\mathrm{w}}$ was $2 \mathrm{dS} \cdot \mathrm{m}^{-1}$ but $\mathrm{pH}$ increased from 6.4 to 7.8 (Fig. 2). In addition, in plants irrigated with acidic water $\mathrm{pH}$, the effect of increasing $\mathrm{EC}_{\mathrm{w}}$ on $\mathrm{K}^{+}$concentration was much higher than when irrigation water had alkaline $\mathrm{pH}$.

Potassium tissue concentration exhibited a negative linear correlation with internal $\mathrm{Mg}^{2+}$ when plants were irrigated with $\mathrm{pH}$ 6.4 water. In 'French Vanilla', the correlation was significant $(r=-0.899 * * *)$ as well as in the LLS of 'Flagstaff' $\left(r=-0.876^{* * *}\right)$ and 'Yellow Climax' $\left(r=-0.921^{* * *}\right)$ and in the LMS of 'Flagstaff' $(r=-0.901 * * *)$ and 'Yellow Climax' $\left(r=-0.935^{* * *}\right)$. However, when the solution $\mathrm{pH}$ was 7.8 , the correlation was significant only for 'Yellow Climax' in the LLS and LMS $\left(r=-0.650^{* *}\right.$ and $r=-0.568^{*}$, respectively). The negative correlation suggests an antagonism between $\mathrm{K}^{+}$and $\mathrm{Mg}^{2+}$ as reported by Ding et al. (2006), Fageria (2001), Marschner (1995), and Troyanos et al. (2000). Results reported by Grunes et al. (1992) and Huang and Grunes (1992) suggest that translocation of $\mathrm{Mg}^{2+}$ is negatively correlated with a high root $\mathrm{K}^{+}$concentration. Potassium content in LLS and LMS was positively correlated with leaf DW in all the three marigold cultivars (Table 5), indicating that the reduced growth may be an effect of impaired enzymatic activity or water relations in $\mathrm{K}^{+}$-deficient plants irrigated with high $\mathrm{EC}_{\mathrm{w}}$ water.

Potassium concentrations in LMS were below the deficiency level for most of the cultivated plants. At harvest time, the LMS in 'Flagstaff' and 'Yellow Climax' developed a marginal chlorosis when plants were irrigated with acidic water and increased $\mathrm{EC}_{\mathrm{w}}$. According to Mills and Benton Jones (1991), a survey average $\mathrm{K}^{+}$concentration in mature $T$. erecta plants grown in 36-cell packs was reported to be $560 \mathrm{mmol} \cdot \mathrm{kg}^{-1}(2.19 \%)$, whereas in T. patula, it was between 714 and $737 \mathrm{mmol} \cdot \mathrm{kg}^{-1}$ (2.79\% to $\left.2.88 \%\right)$. In LMS of 'Flagstaff' and 'Yellow Climax', $\mathrm{K}^{+}$concentration was much lower than these levels when irrigated with high $\mathrm{EC}_{\mathrm{w}}$ (Fig. 2); thus, the marginal chlorosis observed on these leaves may be the result of a deficiency of $\mathrm{K}^{+}$. Compared with the mature leaves of control plants under high $\mathrm{pH}, \mathrm{K}^{+}$concentration was higher when plants were irrigated with $10 \mathrm{dS} \cdot \mathrm{m}^{-1}$ water and yet, no deficiency symptoms were observed; this apparent contradiction may be the result of a concentration effect in $\mathrm{K}^{+}$attributable to the reduced leaf growth under high $\mathrm{EC}_{\mathrm{w}}$. The LLS did not exhibit symptoms of deficiency of $\mathrm{K}^{+}$, probably because $\mathrm{K}^{+}$was retranslocated from the mature leaves to supply the developing leaves. However, the overall effect on aesthetic value was negligible because the mature leaves were hidden by the leaves of the lateral stems.

Sodium. Leaf $\mathrm{Na}^{+}$concentrations were much lower than expected (Fig. 2) because high $\mathrm{Na}^{+}$concentrations in the nutrient solutions were used (Table 1). Increasing $\mathrm{EC}_{\mathrm{w}}$ or $\mathrm{pH}$ of irrigation water in 'Flagstaff' and 'Yellow Climax' had a nonsignificant effect on $\mathrm{Na}^{+}$concentration (Tables 2 and 3); in 'French Vanilla', there was a significant but limited effect of water pH (Table 4). In general, $\mathrm{Na}^{+}$concentrations in marigold were very low as compared with reports for other ornamentals irrigated with water of high salinity. Sodium in leaves of Limonium perezii (Carter et al., 2005a) and Celosia argentea (Carter et al., 2005b), for example, increased from 700 to $1400 \mathrm{mmol} \cdot \mathrm{kg}^{-1}$ and from 200 to $500 \mathrm{mmol} \cdot \mathrm{kg}^{-1}$, respectively, in response to increasing $\mathrm{Na}^{+}$concentrations in saline irrigation waters. However, in our study, marigold concentration in foliar tissue ranged from 15 to $55 \mathrm{mmol} \cdot \mathrm{kg}^{-1}$, suggesting that marigold possesses a mechanism that effectively restricts $\mathrm{Na}^{+}$transport to the leaves. Leaf $\mathrm{Na}^{+}$concentrations in the present experiment are in close agreement with the values reported by Jarecki et al. (2005) with levels of $\approx 44$ to $130 \mathrm{mmol} \mathrm{Na}^{+} / \mathrm{kg}$ in shoots of marigold 'Crackerjack' irrigated with a half-strength Hoagland's solution containing 


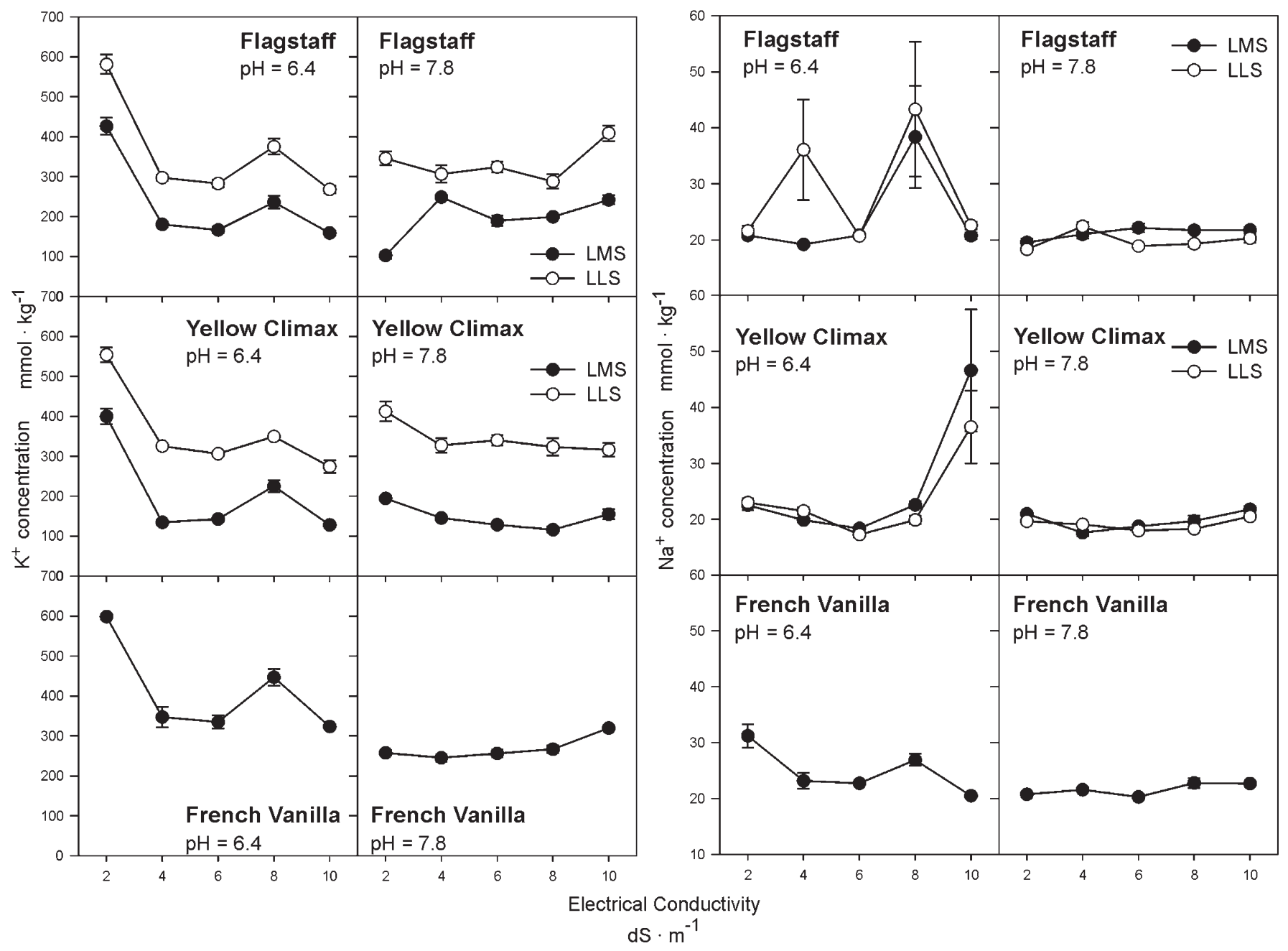

Fig. 2. Potassium and sodium concentration in the leaves of marigold Tagetes patula 'French Vanilla' or in the leaves from the main shoot (LMS) and from the lateral shoots (LLS) in Tagetes erecta 'Flagstaff' and 'Yellow Climax' irrigated with water with increasing electrical conductivity and two pH levels. Values are the means of three observations \pm SE.

$8.4 \mathrm{meq} \mathrm{Na}^{+} / \mathrm{L}$. However, the authors reported root $\mathrm{Na}^{+}$concentrations of $\approx 740$ mmol $\cdot \mathrm{kg}^{-1}$, indicating that $\mathrm{Na}^{+}$was sequestered in the root. We also found evidence of limited partitioning of $\mathrm{Na}^{+}$stem tissues, which was effective until $\mathrm{EC}_{\mathrm{w}}$ exceeded 6 $\mathrm{dS} \cdot \mathrm{m}^{-1}$ (Table 6).

Sodium exclusion capacity would explain the absence of correlation between leaf $\mathrm{Na}^{+}$ concentration and plant growth (data not shown), although it is important to consider that the energy the plants must have spent for the exclusion of $\mathrm{Na}^{+}$may have negatively impacted growth. Our results are also in agreement with those reported by Huang and Cox (1988) who observed a slight (from $195 \mathrm{ppm}$ in the control with $\mathrm{EC}_{\mathrm{w}} 1.3 \mathrm{dS} \cdot \mathrm{m}^{-1}$ to $215 \mathrm{ppm}$ in plants irrigated with $\mathrm{EC}_{\mathrm{w}} 7.9$ $\mathrm{dS} \cdot \mathrm{m}^{-1}$ water) increase in leaf $\mathrm{Na}^{+}$concentration of marigold plants cultivated in a peatbased medium and irrigated with increasing concentrations of a $\mathrm{NaCl}+\mathrm{CaCl}_{2}$ mixture. Huang and Cox (1988) reported a 7.4 to 20.4 times higher $\mathrm{Na}^{+}$concentration in the roots than in the shoot of marigold, suggesting a restricted translocation of $\mathrm{Na}^{+}$under saline conditions.
High $\mathrm{K}^{+}: \mathrm{Na}^{+}$ratios have been considered reliable markers for tolerance to salinity (Juan et al., 2005; Maathuis and Amtmann, 1999). Sodium exclusion in marigold may have increased the tolerance to salinity because $\mathrm{K}^{+}$was not significantly affected when $\mathrm{EC}_{\mathrm{w}}$ increased from 4 to $10 \mathrm{dS} \cdot \mathrm{m}^{-1}$ (Fig. 2); thus, a lower $\mathrm{Na}^{+}$concentration combined with a less affected $\mathrm{K}^{+}$may have resulted in a higher $\mathrm{K}^{+}: \mathrm{Na}^{+}$ratio. In 'Flagstaff', the $\mathrm{K}^{+}: \mathrm{Na}^{+}$ratio was 27.4 in the LLS of plants irrigated with water of $\mathrm{EC}_{\mathrm{w}} 2 \mathrm{dS} \cdot \mathrm{m}^{-1}$, but increasing salinity to $4 \mathrm{dS} \cdot \mathrm{m}^{-1}$ caused a decrease to 11.8. Nonetheless, the $\mathrm{K}^{+}: \mathrm{Na}^{+}$ ratio was not further decreased as salinity of irrigation water rose to $10 \mathrm{dS} \cdot \mathrm{m}^{-1}$ and varied between 11.8 and 14.9 (data not shown), a considerably higher value than that reported for Matthiola incana (Grieve et al., 2006).

Phosphorus and sulfur. EC and $\mathrm{pH}$ of irrigation water significantly affected total phosphorus $(\mathrm{P})$ concentration in the three marigold cultivars (Tables 2-4), whereas the $\mathrm{pH} \times \mathrm{EC}_{\mathrm{w}}$ interaction was significant only for 'French Vanilla' (Table 4). Leaf total $\mathrm{P}$ of plants irrigated with acid water increased in a cubic trend when $\mathrm{EC}_{\mathrm{w}}$ increased up to $6 \mathrm{dS} \cdot \mathrm{m}^{-1}$, but when $\mathrm{EC}_{\mathrm{w}}$ was higher than $8 \mathrm{dS} \cdot \mathrm{m}^{-1}$, total $\mathrm{P}$ concentration decreased to the level of the control plants (Fig. 3). Total sulfur (S) exhibited similar responses as total $\mathrm{P}$.

It has been proposed that $\mathrm{P}$ concentration increases in salinity studies performed in sand or solution cultures as a result of the higher P supply (Grattan and Grieve, 1999); however, our results contrast with other reports in which plants were grown under comparable conditions. Carter et al. (2005a, $2005 \mathrm{~b}$ ) reported a negative correlation between total $\mathrm{P}$ concentration and total $\mathrm{S}$ and $\mathrm{Cl}^{-}$concentration when Limonium perezii and Celosia argentea plants were irrigated with water of similar composition to the one used in our study. Although Hu and Schmidhalter (2005) reported that competition between $\mathrm{Cl}^{-}$and $\mathrm{H}_{2} \mathrm{PO}_{4}^{-}$is unlikely, several reports indicate that $\mathrm{Cl}^{-}$reduces $\mathrm{P}$ (Papadopoulos and Rendig, 1983) and $\mathrm{SO}_{4}{ }^{2-}$ uptake (Papadopoulos, 1987; Papadopoulos et al., 1985). Negative correlations between total $P$ and total $\mathrm{S}$ and total $\mathrm{P}$ and $\mathrm{Cl}^{-}$were also reported in Ranunculus asiaticus (Valdez-Aguilar et al., 2009a), suggesting some competition 
between $\mathrm{P}$ and $\mathrm{S}$ or $\mathrm{Cl}^{-}$. In contrast, in the present study, a positive relationship between total $\mathrm{P}$ and total $\mathrm{S}$ concentration was found in all the three marigold cultivars when irrigation water $\mathrm{pH}$ was 6.4 (Fig. 3), but not with $\mathrm{Cl}^{-}$(Fig. 4). The correlation coefficients between total $\mathrm{P}$ and total $\mathrm{S}$ concentration in 'Flagstaff' and 'Yellow Climax' were significant for the LMS $\left(r=+0.621^{*}\right.$ and $r=$ $+0.577^{*}$, respectively) and for the LLS ( $r=$ $+0.593 *$ and $r=+0.683^{* *}$, respectively) and for 'French Vanilla' $(r=+0.661 * *)$.

Table 6. Significance of trends and the effect of electrical conductivity of irrigation water $\left(\mathrm{EC}_{\mathrm{w}}\right), \mathrm{pH}$, and $\mathrm{pH} \times \mathrm{EC}_{\mathrm{w}}$ interaction on sodium and chloride concentration in stems of three cultivars of marigold.

\begin{tabular}{|c|c|c|c|c|c|c|c|c|c|c|c|c|}
\hline \multirow{4}{*}{$\begin{array}{l}\mathrm{EC}_{\mathrm{w}} \\
\left(\mathrm{dS} \cdot \mathrm{m}^{-1}\right)\end{array}$} & \multicolumn{4}{|c|}{ Flagstaff } & \multicolumn{4}{|c|}{ Yellow Climax } & \multicolumn{4}{|c|}{ French Vanilla } \\
\hline & \multicolumn{2}{|c|}{$\mathrm{Na}^{+}$} & \multicolumn{2}{|c|}{$\mathrm{Cl}^{-}$} & \multicolumn{2}{|c|}{$\mathrm{Na}^{+}$} & \multicolumn{2}{|c|}{$\mathrm{Cl}^{-}$} & \multicolumn{2}{|c|}{$\mathrm{Na}^{+}$} & \multicolumn{2}{|c|}{$\mathrm{Cl}^{-}$} \\
\hline & $\mathrm{pH}$ & $\mathrm{pH}$ & $\mathrm{pH}$ & $\mathrm{pH}$ & $\mathrm{pH}$ & $\mathrm{pH}$ & $\overline{\mathrm{pH}}$ & $\mathrm{pH}$ & $\mathrm{pH}$ & $\mathrm{pH}$ & $\overline{\mathrm{pH}}$ & $\mathrm{pH}$ \\
\hline & 6.4 & 7.8 & $\overline{6.4}$ & 7.8 & 6.4 & 7.8 & $\overline{6.4}$ & 7.8 & 6.4 & 7.8 & $\overline{6.4}$ & 7.8 \\
\hline 2 & 17.7 & 13.0 & 226 & 164 & 16.5 & 16.2 & 261 & 146 & 16.8 & 17.7 & 114 & $\overline{132}$ \\
\hline 4 & 45.9 & 64.3 & 634 & 876 & 39.2 & 9.1 & 740 & 700 & 55.2 & 51.5 & 501 & 758 \\
\hline 6 & 88.2 & 91.6 & 751 & 971 & 102.2 & 36.1 & 785 & 869 & 86.0 & 62.3 & 651 & 834 \\
\hline 8 & 134.5 & 57.0 & 688 & 1035 & 179.0 & 28.1 & 801 & 1049 & 272.0 & 169.3 & 816 & 1116 \\
\hline 10 & 180.3 & 282.7 & 767 & 1124 & 195.0 & 97.2 & 921 & 1225 & 236.0 & 272.3 & 887 & 1141 \\
\hline $\mathrm{L}^{\mathrm{zy}}$ & $* * *$ & $* * *$ & $* * *$ & $* * *$ & $* * *$ & $* * *$ & $* * *$ & $* * *$ & $* * *$ & $* * *$ & $* * *$ & $* * *$ \\
\hline Q & NS & $*$ & $* * *$ & $* * *$ & NS & $*$ & $* * *$ & $* * *$ & NS & NS & $* * *$ & $* * *$ \\
\hline C & NS & $*$ & $* * *$ & $* * *$ & NS & NS & $* * *$ & $* *$ & $*$ & & NS & $*$ \\
\hline $\mathrm{EC}_{\mathrm{w}}$ & \multicolumn{2}{|c|}{$* * *$} & \multicolumn{2}{|c|}{$* * *$} & \multicolumn{2}{|c|}{$* * *$} & \multicolumn{2}{|c|}{$* * *$} & \multicolumn{2}{|c|}{$* * *$} & \multicolumn{2}{|c|}{$* * *$} \\
\hline $\mathrm{pH}$ & \multicolumn{2}{|c|}{ NS } & \multicolumn{2}{|c|}{$* * *$} & \multicolumn{2}{|c|}{$* * *$} & \multicolumn{2}{|c|}{$* * *$} & \multicolumn{2}{|c|}{ NS } & \multicolumn{2}{|c|}{$* * *$} \\
\hline $\operatorname{Int}^{\mathrm{x}}$ & \multicolumn{2}{|c|}{ NS } & \multicolumn{2}{|c|}{$* * *$} & \multicolumn{2}{|c|}{$* *$} & \multicolumn{2}{|c|}{$* * *$} & \multicolumn{2}{|c|}{ NS } & \multicolumn{2}{|c|}{$* *$} \\
\hline
\end{tabular}

${ }^{\mathrm{z}} \mathrm{L}, \mathrm{Q}, \mathrm{C}=$ lineal, quadratic, and cubic trends, respectively.

${ }_{\mathrm{NS}}, *, * *, * * *=$ Nonsignificant and significant at $P<0.05, P<0.01$, and $P<0.001$, respectively.

Interaction $\mathrm{pH} \times \mathrm{EC}_{\mathrm{w}}$.

Increasing the $\mathrm{pH}$ of irrigation water to 7.8 significantly increased total $\mathrm{P}$ concentration in the three marigold cultivars (Tables 2 4) compared with plants irrigated with water of $\mathrm{pH} 6.4$ (Fig. 3). The higher $\mathrm{pH}$ treatment was responsible for an increase in total $\mathrm{P}$ in the LLS of 'Flagstaff' and 'Yellow Climax' of $112 \%$ and $55 \%$, respectively, whereas in the LMS, the increase was $223 \%$ and $128 \%$, respectively. In 'French Vanilla', the increase in total $\mathrm{P}$ was $50 \%$. Alkaline $\mathrm{pH}$ combined with increasing $\mathrm{EC}_{\mathrm{w}}$ appears to invoke a synergistic effect because total $\mathrm{P}$ increased at a higher rate (Fig. 3). To a certain extent, this effect was unexpected because under alkaline conditions, the formation of calcium phosphates is higher, reducing availability of soluble $\mathrm{P}$ and reducing plant uptake and accumulation. However, total $\mathrm{P}$ accumulation [found by calculating total P content according to leaf dry weight (data not shown)] was not altered by $\mathrm{pH}$, suggesting that $\mathrm{pH}$ of water increased total $\mathrm{P}$ concentration as salinity decreased plant growth. High alkalinity, however, decreased plant DW accumulation. Salinity also appears to affect total $\mathrm{P}$ concentration in the foliage through a decrease in plant growth. Total P in 'Yellow

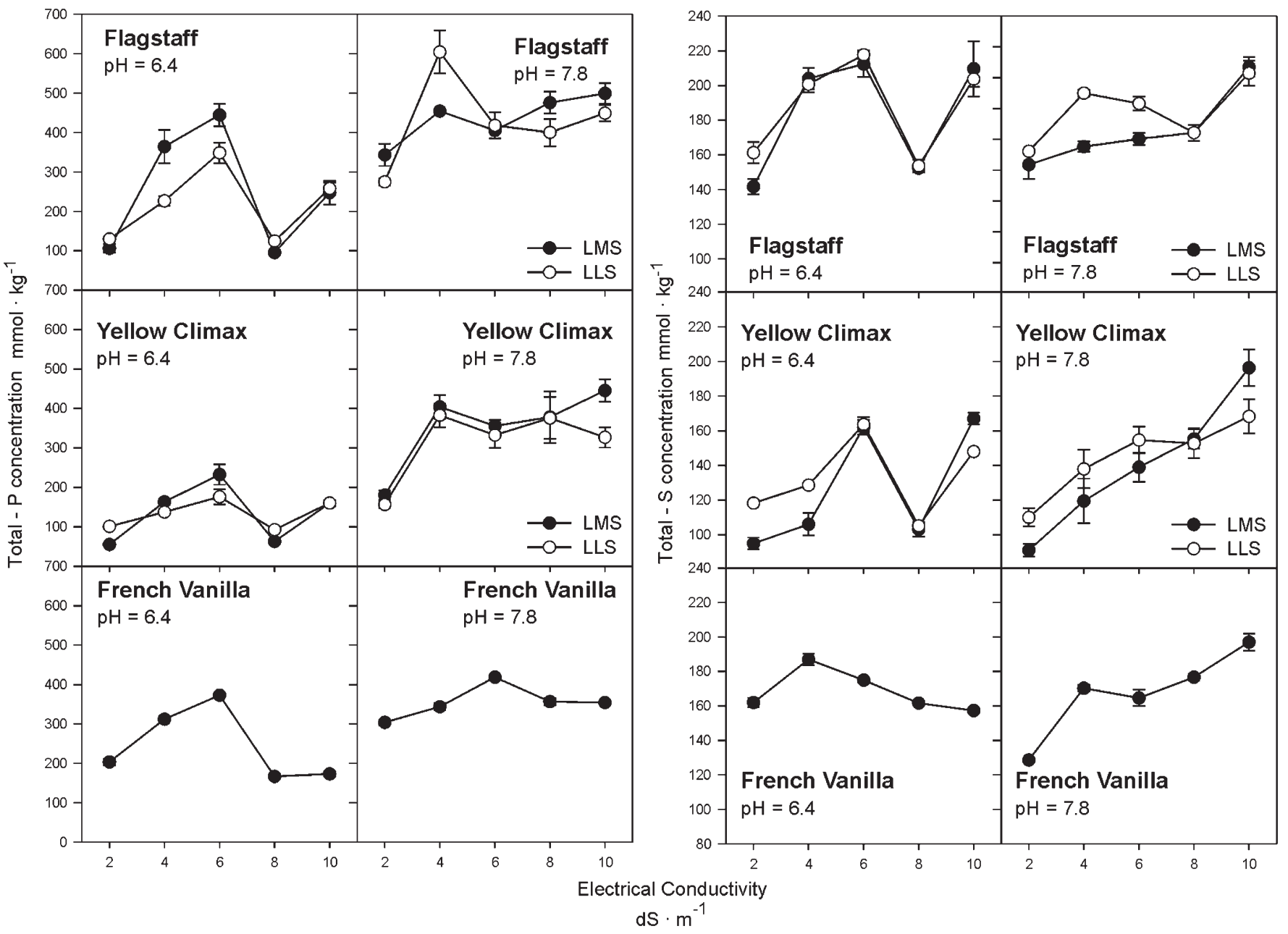

Fig. 3. Total phosphorus and total sulfur concentration in the leaves of marigold Tagetes patula 'French Vanilla' or in the leaves from the main shoot (LMS) and from the lateral shoots (LLS) in Tagetes erecta 'Flagstaff' and 'Yellow Climax' irrigated with water with increasing electrical conductivity and two pH levels. Values are the means of three observations $\pm \mathrm{SE}$. 


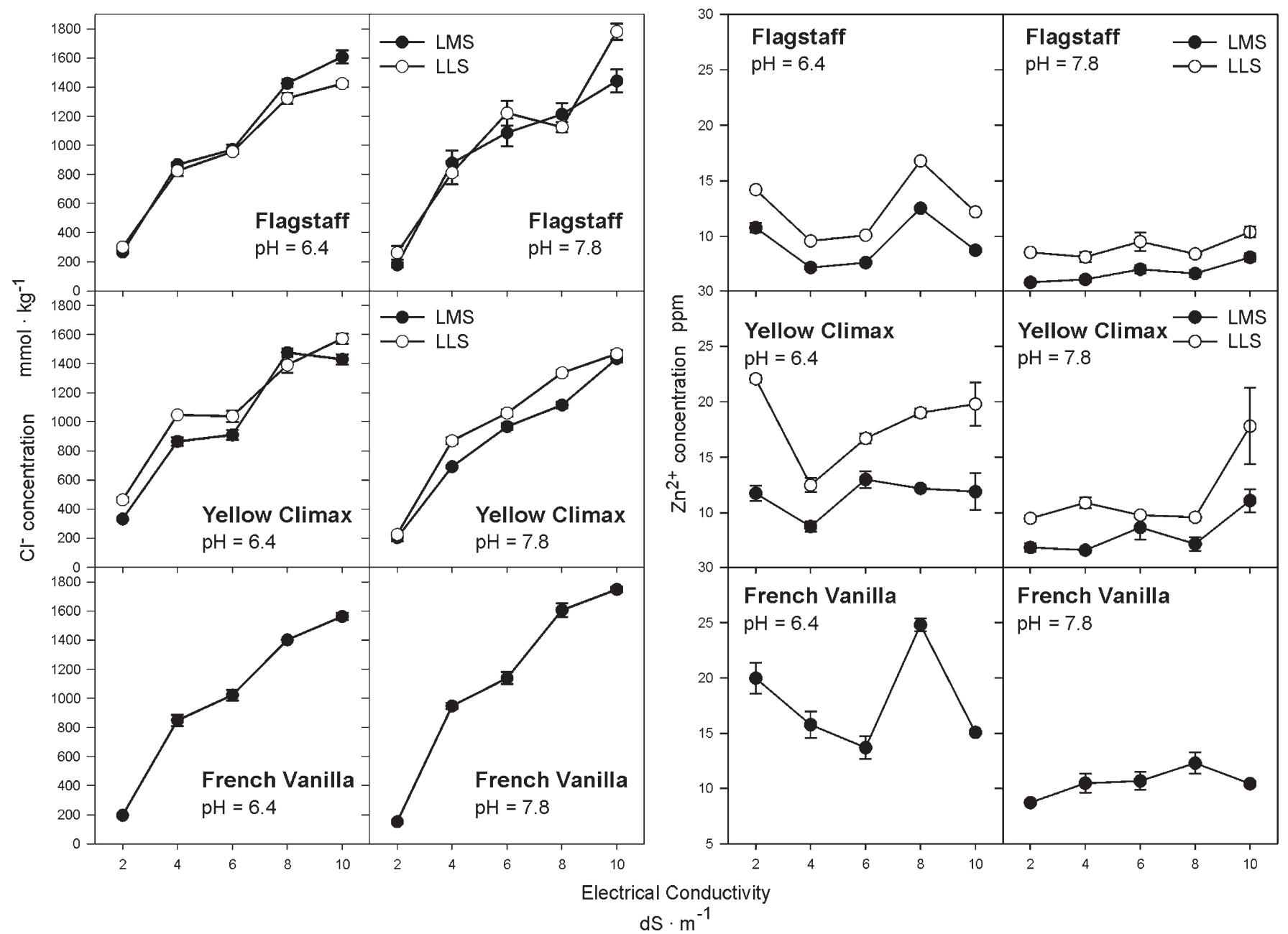

Fig. 4. Chloride and zinc concentration in the leaves of marigold Tagetes patula 'French Vanilla' or in the leaves from the main shoot (LMS) and from the lateral shoots (LLS) in Tagetes erecta 'Flagstaff' and 'Yellow Climax' irrigated with water with increasing electrical conductivity and two pH levels. Values are the means of three observations $\pm \mathrm{SE}$.

Climax' varied between 0.97 and $1.60 \mathrm{mg} /$ plant and 1.06 and $1.66 \mathrm{mg} / \mathrm{plant}$ when irrigation water $\mathrm{pH}$ was 6.4 and 7.8 , respectively.

Chloride. Irrigation with saline water significantly increased $\mathrm{Cl}^{-}$concentration in the three marigold cultivars (Tables 2-4; Fig. 4). The increase followed a linear trend and was significant when $\mathrm{EC}_{\mathrm{w}}$ was $4 \mathrm{dS} \cdot \mathrm{m}^{-1}$ or higher. The linear trend suggests that $\mathrm{Cl}^{-}$ uptake was a function of external concentration, as also reported by Hajrasuliha (1980) in bean plants. Leaf position had no effect on $\mathrm{Cl}^{-}$concentration in individual leaves along the main shoot axis and indicates that the anion is highly mobile. Ben-Gal and Shani (2002) reported similar trends in tomato. Leaf and stem $\mathrm{Cl}^{-}$concentrations increased as irrigation water salinity increased. In our study, internal $\mathrm{Cl}^{-}$and $\mathrm{Mg}^{2+}$ concentration were correlated; in general, increasing $\mathrm{Mg}^{2+}$ was positively correlated with increasing $\mathrm{Cl}^{-}$, which probably is a mechanism for the maintenance of charge balance. In 'Flagstaff' irrigated with water of $\mathrm{pH} 6.4$, in the LLS, the correlation was $r=+0.817^{* * *}$, whereas in the LMS, it was $r=+0.730^{* *}$. In the LLS of 'Yellow Climax', the correlation was $r=$
$+0.894^{* * *}$, whereas in the LMS, the correlation was $r=+0.773 * * *$. In 'French Vanilla', the correlation was $r=+0.653 * *$. Similar correlations were observed when the $\mathrm{pH}$ of the irrigation water was 7.8.

Healthy leaves of pistachio trees contain

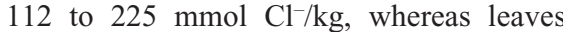
containing $535 \mathrm{mmol} \cdot \mathrm{kg}^{-1}$ exhibited severe marginal leaf scorching (Ashworth et al., 1985). Marigold exhibited a remarkable capacity to assimilate $\mathrm{Cl}^{-}$, reaching concentrations close to $1500 \mathrm{mmol} \cdot \mathrm{kg}^{-1}$. Because even the younger leaves contained high $\mathrm{Cl}^{-}$ levels, it is unlikely that $\mathrm{Cl}^{-}$toxicity was responsible for the marginal chlorosis of the mature leaves mentioned previously. Saltstressed tomato reportedly contained $\mathrm{Cl}^{-}$concentrations in the range of 10 to $15 \mathrm{mmol} \cdot \mathrm{kg}^{-1}$ in leaves, 8 to $10 \mathrm{mmol} \cdot \mathrm{kg}^{-1}$ in stems, and 4 to $5 \mathrm{mmol} \cdot \mathrm{kg}^{-1}$ in fruits (Ben-Gal and Shani, 2002). However, Pantalone et al. (1997) reported in susceptible soybean cultivars, leaf chlorosis was associated with $\mathrm{Cl}^{-}$concentrations between 1507 and $2375 \mathrm{mmol} \cdot \mathrm{kg}^{-1}$, whereas in tolerant cultivars, $\mathrm{Cl}^{-}$ranged between 96 and $375 \mathrm{mmol} \cdot \mathrm{kg}^{-1}$, probably as a result of an effective $\mathrm{Cl}^{-}$exclusion mechanism. The $\mathrm{Cl}^{-}$exclusion mechanism was not detected in marigold as demonstrated by the concentrations in the stems (Table 6), which were comparable or even lower than those of the leaves.

Micronutrients. The effect of $\mathrm{EC}_{\mathrm{w}}$ and $\mathrm{pH}$ on the internal $\mathrm{Zn}^{2+}$ concentration in marigold 'Flagstaff' (Table 2) and 'French Vanilla' (Table 4) was significant, whereas in 'Yellow Climax', $\mathrm{Zn}^{2+}$ accumulation was only affected by solution $\mathrm{pH}$ (Table 3 ). In general, the response of leaf $\mathrm{Zn}^{2+}$ to increasing $\mathrm{EC}_{\mathrm{w}}$ was not consistent (Fig. 4); however, $\mathrm{Zn}^{2+}$ significantly decreased at a higher $\mathrm{pH}$ of irrigation water. Alkalinity is considered the major $\mathrm{Zn}^{2+}$ deficiency-causing factor in plants (Yang et al., 1993). Copper concentration was significantly affected by salinity of irrigation water in 'Flagstaff' and 'Yellow Climax' and by $\mathrm{pH}$ in all three marigold cultivars (Tables 2-4). As indicated for $\mathrm{Zn}^{2+}$, $\mathrm{Cu}^{2+}$ concentration in response to increasing $\mathrm{EC}_{\mathrm{w}}$ exhibited a nonconsistent pattern (Fig. $5)$; in general, the higher $\mathrm{pH}$ caused a significant decrease in $\mathrm{Cu}^{2+}$ content in LLS of 'Yellow Climax' and 'French Vanilla'. The $\mathrm{pH}$ effect was also associated with a decrease in internal $\mathrm{Cu}^{2+}$ concentration in the LLS of the three marigold cultivars. Internal 


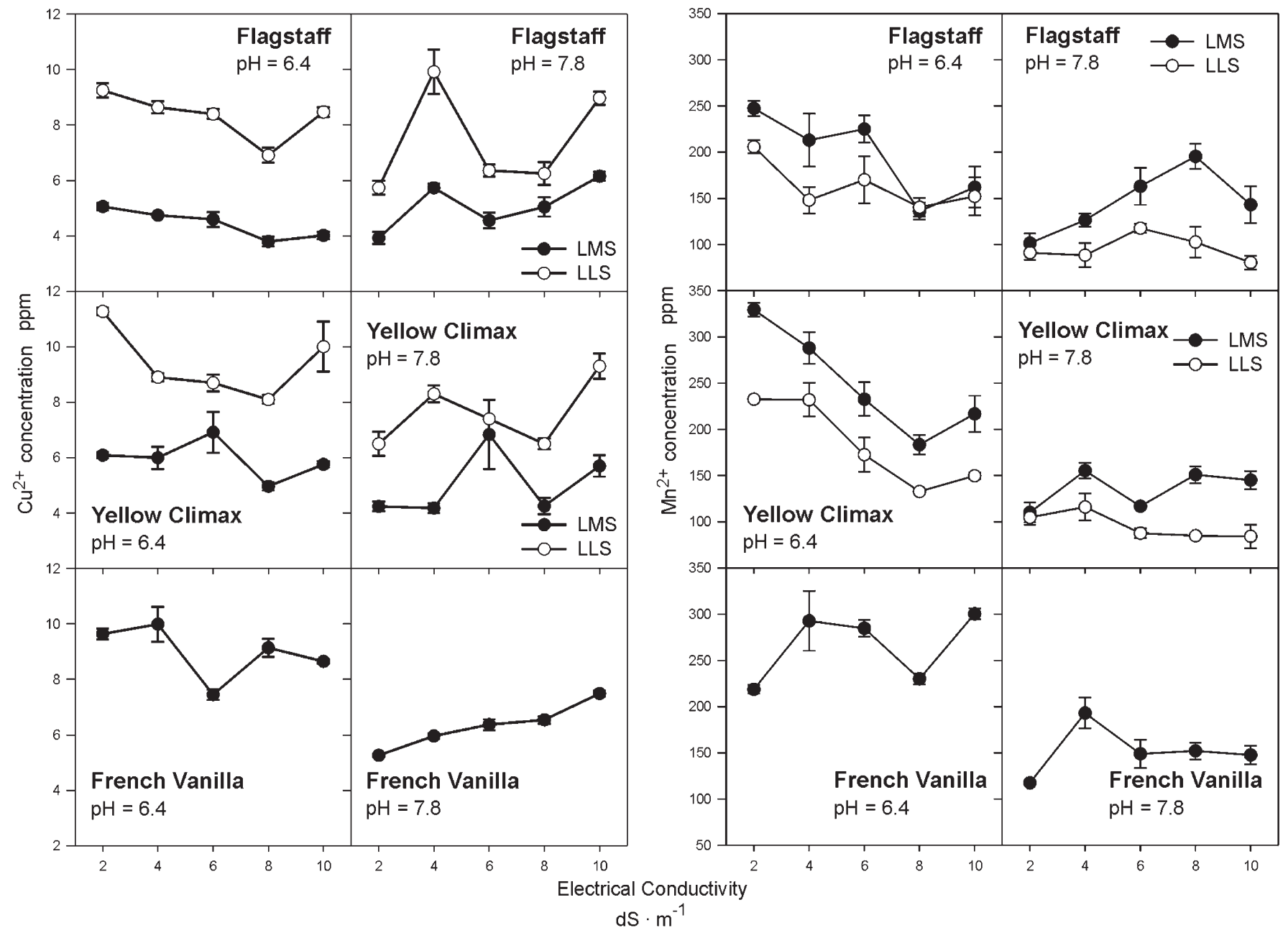

Fig. 5. Copper and manganese concentration in the leaves of marigold Tagetes patula 'French Vanilla' or in the leaves from the main shoot (LMS) and from the lateral shoots (LLS) in Tagetes erecta 'Flagstaff' and 'Yellow Climax' irrigated with water with increasing electrical conductivity and two pH levels. Values are the means of three observations $\pm \mathrm{SE}$.

$\mathrm{Mn}^{2+}$ concentration tended to decrease with increasing $\mathrm{EC}_{\mathrm{w}}$ in plants of 'Flagstaff' and 'Yellow Climax' when $\mathrm{pH}$ was 6.4 , but this response was only significant in 'Yellow Climax' (Tables 2-4). As indicated for $\mathrm{Cu}^{2+}$ and $\mathrm{Zn}^{2+}$, alkaline $\mathrm{pH}$ significantly reduced leaf $\mathrm{Mn}^{2+}$ concentration (Fig. 5). High irrigation water $\mathrm{pH}$ has been associated with decreased $\mathrm{Fe}^{2+}$ uptake and leaf chlorosis (Römheld, 2000). However, in the present study, internal $\mathrm{Fe}^{2+}$ concentration did not show a consistent trend with increasing salinity or $\mathrm{pH}$ of irrigation water (Fig. 6), perhaps as a result of the chelated $\mathrm{Fe}(\mathrm{Fe}-$ DTPA) used in our nutrient solution.

In summary, increasing salinity appears to have little effect on micronutrient nutrition in marigold, a finding in agreement with reports by Eom et al. (2007) who found that $\mathrm{NaCl}$ salinity applied to six groundcover species had no effect on $\mathrm{Fe}^{2+}$ and $\mathrm{Zn}^{2+}$ accumulation, increased $\mathrm{Mn}^{2+}$ in Alchemilla mollis and Solidago cutleri, and decreased $\mathrm{Cu}^{2+}$ in Nepeta $\times$ faassenii. However, in our study, a higher $\mathrm{pH}$ in irrigation water caused decreased leaf $\mathrm{Zn}^{2+}, \mathrm{Cu}^{2+}$, and $\mathrm{Mn}^{2+}$ concentrations, which ranged between $50 \%$ to $223 \%, 22 \%$ to $445 \%$, and $46 \%$ to $67 \%$, respectively. However, when micronutrient foliar content was calculated, a significant positive regression with leaf DW was detected (Table 5). No visual symptoms of micronutrient deficiencies were observed. Therefore, the positive correlation may be related to the lower growth rate resulting from the osmotic effects of salinity.

Plant growth, aesthetic value, and nutrient status. The effect of increasing $\mathrm{EC}_{\mathrm{w}}$ and $\mathrm{pH}$ on plant shoot DW is reported in a companion paper (Valdez-Aguilar et al., $2009 b)$. Internal $\mathrm{K}^{+}$concentration and shoot DW production were positively correlated (Fig. 6), suggesting that the reduction in $\mathrm{K}^{+}$ resulting from higher salinity was associated with lower DW. On the other hand, a negative correlation between $\mathrm{Mg}^{2+}$ and shoot DW (Fig. 6) indicates that the increase in internal $\mathrm{Mg}^{2+}$ was associated with growth reduction. Similarly, shoot DW exhibited a quadratic decrease with internal $\mathrm{Cl}^{-}$concentration (Fig. 6), corroborating that marigold, in common with other crops, is very sensitive to high $\mathrm{Cl}^{-}$ (Grattan and Grieve, 1999). Estañ et al. (2005) reported a negative correlation be- tween leaf $\mathrm{Cl}^{-}$concentration and yield of tomato plants grown at high $\mathrm{NaCl}$ concentrations, indicating that the most productive plants were those with the ability to regulate the transport of toxic ions. These correlations were not detected in marigold plants irrigated with water with $\mathrm{pH}$ 7.8. Martin and Koebner (1995) indicate that in bean plants grown under high salinity, $\mathrm{Cl}^{-}$exerted a higher toxicity than $\mathrm{Na}^{+}$, reducing plant growth; this was explained by the increased influx of $\mathrm{Cl}^{-}$resulting from the perturbation of $\mathrm{Ca}^{2+}$ homeostasis in the plasmalemma. The authors also reported that $\mathrm{Mg}^{2+}$ was phytotoxic under such conditions.

Although plant growth was significantly reduced as salinity increased in waters with $\mathrm{pH} \mathrm{6.4,} \mathrm{the} \mathrm{aesthetic} \mathrm{quality} \mathrm{of} \mathrm{these} \mathrm{mari-}$ gold cultivars was not compromised, making them valuable for landscape sites where degraded waters are used for irrigation. The overall health of the marigold species was undoubtedly the result of favorable ion balances and interactions within the plant, including the nonsignificant effect on $\mathrm{Ca}^{2+}$ in the LLS of 'Flagstaff' and 'Yellow Climax' (Fig. 1), the attenuation of $\mathrm{Mg}^{2+}$ 

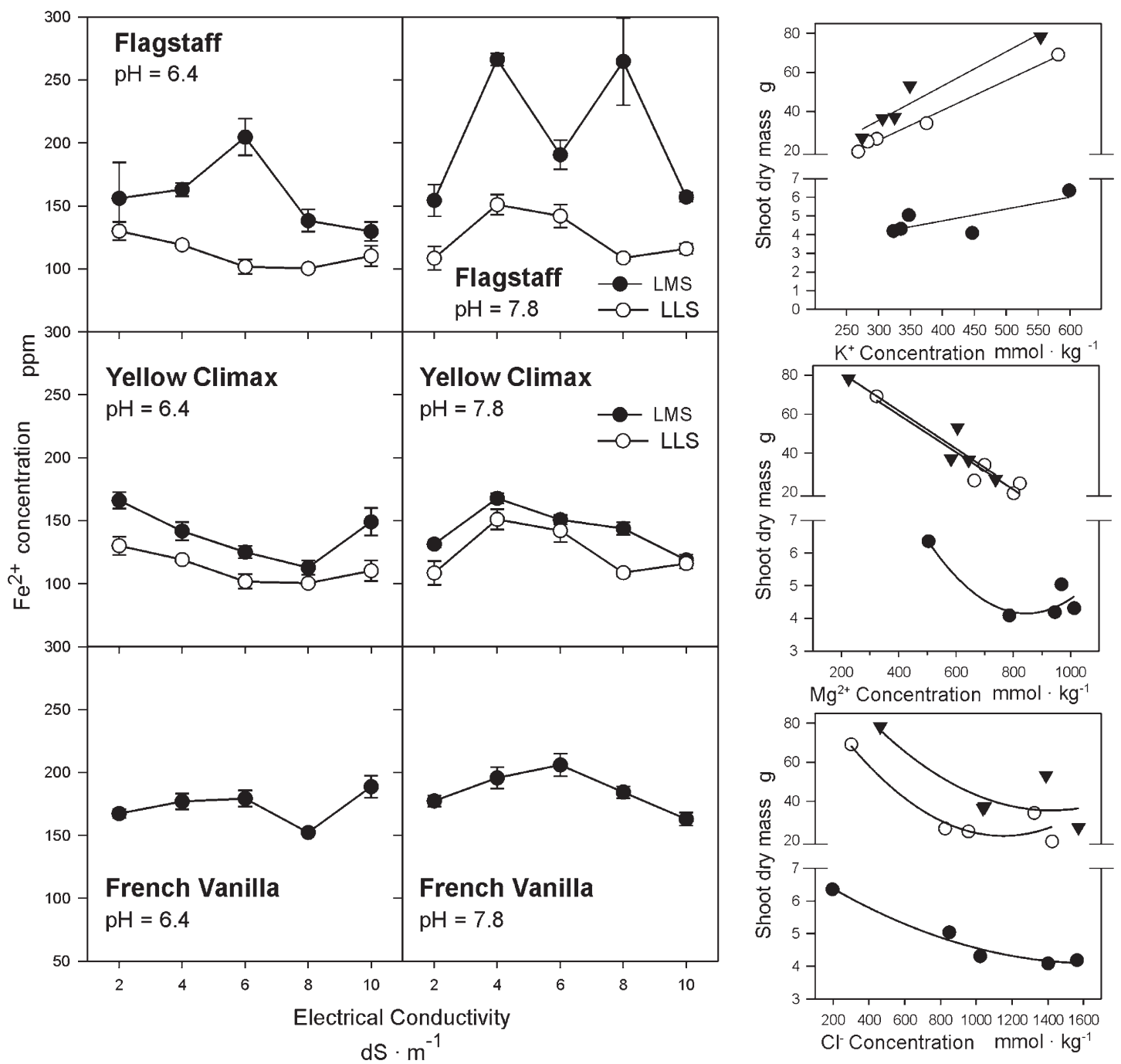

Fig. 6. Iron concentration in the leaves of marigold Tagetes patula 'French Vanilla' or in the leaves from the main shoot (LMS) and from the lateral shoots (LLS) in Tagetes erecta 'Flagstaff' and 'Yellow Climax' irrigated with water with increasing electrical conductivity and two pH levels. Values are the means of three observations \pm se and relationship between $\mathrm{K}^{+}, \mathrm{Mg}^{2+}$, and $\mathrm{Cl}^{-}$concentration in the leaves of marigold 'French Vanilla' $(\bullet)$ or the leaves from the lateral shoots of 'Flagstaff' $(\odot)$ and 'Yellow Climax' $(\boldsymbol{\nabla})$ and the shoot dry weight produced at experiment termination.

accumulation (Fig. 1) or decrease in $\mathrm{K}^{+}$(Fig. 2) when $\mathrm{EC}_{\mathrm{w}}$ was $4 \mathrm{dS} \cdot \mathrm{m}^{-1}$ or higher, and the effects on total $\mathrm{P}$ concentration in response to increasing $\mathrm{EC}_{\mathrm{w}}$ (Fig. 3), and $\mathrm{Na}^{+}$exclusion, which resulted in a low leaf $\mathrm{Na}^{+}: \mathrm{K}^{+}$ratio and a high selectivity for $\mathrm{K}^{+}$.

\section{Conclusions}

Growth of marigold plants irrigated with water at $\mathrm{pH} 6.4$ significantly decreased as $\mathrm{EC}_{\mathrm{w}}$ increased; however, the aesthetic value of the plants was not detrimentally affected. As suggested in a companion paper (ValdezAguilar et al., 2009b), growth reduction may be associated with the osmotic effects when plants were irrigated with solution of high $\mathrm{EC}_{\mathrm{w}}$. The maintenance of a high ornamental value in flowering stems of the salt-stressed marigolds may have been associated with specific mineral ion relations such as the nonsignificant effect on $\mathrm{Ca}^{2+}$ in the LLS of 'Flagstaff' and 'Yellow Climax', the attenuation of $\mathrm{Mg}^{2+}$ accumulation, the plateau in $\mathrm{K}^{+}$ reduction when $\mathrm{EC}_{\mathrm{w}}$ was $4 \mathrm{dS} \cdot \mathrm{m}^{-1}$ or higher, and the exclusion of $\mathrm{Na}^{+}$. Considering only the $\mathrm{pH}$ effect, it caused a severe reduction in landscape attributes of marigold, which was associated with a significant decrease in $\mathrm{K}^{+}$, $\mathrm{Zn}^{2+}$, and $\mathrm{Cu}^{2+}$ concentration and a significant increase in $\mathrm{Mg}^{2+}$.

Aesthetic factors for evaluating ornamental landscape plants include attractiveness, size, and health. In some cases, growth may be reduced as much as $50 \%$ as long as plant appearance remains acceptable. Maximum permissible salinity levels for plants grown in landscape sites are generally based on soil salinity [EC of the saturated soil paste $\left.\left(\mathrm{EC}_{\mathrm{e}}\right)\right]$. As a result of the soil-water dynamics of our sand tank system, the $\mathrm{EC}_{\mathrm{w}}$ of the irrigation waters is $\approx 2.2$ times that of the $\mathrm{EC}_{\mathrm{e}}$. The marigold cultivars retained aesthetic value and exhibited acceptable growth when $\mathrm{EC}_{\mathrm{w}}$ was as high as $8 \mathrm{dS} \cdot \mathrm{m}^{-1}$ (equivalent $\mathrm{EC}_{\mathrm{e}}=$ $3.64 \mathrm{dS} \cdot \mathrm{m}^{-1}$ ). Although many environmental and edaphic factors will influence the response of the marigold to salinity, the cultivars are recommended for moderately saline landscape settings.

\section{Literature Cited}

Ashworth, L.J., S.A. Gaona, and E. Surber. 1985. Nutritional diseases of pistachio trees: Potassium and phosphorus deficiencies and chloride and boron toxicities. Phytopathology 75:10841091.

Ayers, R.S. and D.W. Westcot. 1985. Water quality for agriculture. FAO Irrigation and Drainage Paper 29 Rev. 1. Food and Agriculture Organization of the United Nations, Rome, Italy.

Ben-Gal, A. and U. Shani. 2002. Yield, transpiration and growth of tomatoes under combined excess boron and salinity stress. Plant Soil 247:211-221.

Carter, C.T., C.M. Grieve, and J.A. Poss. 2005a. Salinity effects on emergence, survival, and ion accumulation of Limonium perezii. J. Plant Nutr. 28:1243-1257.

Carter, C.T., C.M. Grieve, J.A. Poss, and D.L. Suarez. 2005b. Production and ion uptake of Celosia argentea irrigated with saline wastewaters. Scientia Hort. 106:381-394. 
Carvajal, M., A. Cerdá, and V. Martínez. 2000. Modification of the response of saline stressed tomato plants by the correction of cation disorders. Plant Growth Regulat. 30:37-47.

Carvajal, M., V. Martínez, and A. Cerdá. 1999. Influence of magnesium and salinity on tomato plants grown in hydroponic culture. J. Plant Nutr. 22:177-190.

Cramer, G.R., A. Läuchli, and V.S. Polito. 1985. Displacement of $\mathrm{Ca}^{2+}$ by $\mathrm{Na}^{+}$from the plasmalemma of root cells. Plant Physiol. 79:207-211.

Ding, Y., W. Luoi, and G. Xu. 2006. Characterization of magnesium nutrition and interaction of magnesium and potassium in rice. Ann. Appl. Biol. 149:111-123.

Eom, S.H., T.L. Setter, A. DiTommaso, and L.A. Weston. 2007. Differential growth response to salt stress among selected ornamentals. J. Plant Nutr. 30:1109-1126.

Estañ, M.T., M.M. Martínez-Rodriguez, F. PerezAlfocea, T.J. Flowers, and M.C. Bolarin. 2005. Grafting raises the salt tolerance of tomato through limiting the transport of sodium and chloride to the shoot. J. Expt. Bot. 56:703-712.

Fageria, V.D. 2001. Nutrient interactions in crop plants. J. Plant Nutr. 24:1269-1290.

Grattan, S.R. and C.M. Grieve. 1999. Salinitymineral nutrient relations in horticultural crops. Scientia Hort. 78:127-157.

Grieve, C.M., J.A. Poss, and C. Amrhein. 2006. Response of Matthiola incana to irrigation with saline wastewaters. HortScience 41:119123.

Grunes, D.L., J.W. Huang, F.W. Smith, P.K. Joo, and D.A. Hewes. 1992. Potassium effects on minerals and organic-acids in 3 cool-season grasses. J. Plant Nutr. 15:1007-1025.

Hajrasuliha, S. 1980. Accumulation and toxicity of chloride in bean plants. Plant Soil 55:133-138.

$\mathrm{Hu}, \mathrm{Y}$. and U. Schmidhalter. 2005. Drought and salinity: A comparison of their effects on mineral nutrition of plants. J. Plant Nutr. Soil Sci. 168:541-549.

Huang, J.W. and D.L. Grunes. 1992. Effects of root temperature and nitrogen form in magnesium uptake and translocation by wheat seedlings. J. Plant Nutr. 15:991-1005.

Huang, Z.T. and D.A. Cox. 1988. Salinity effects on annual bedding plants in a peat-perlite medium and solution culture. J. Plant Nutr. 11:145-159.

Islam, A.K.M.S., D.G. Edwards, and C.J. Asher. 1980. pH optima for crop growth. Plant Soil 54:339-357.

Jarecki, M.K., C. Chong, and R.P. Voroney. 2005. Evaluation of compost leachates for plant growth in hydroponic culture. J. Plant Nutr. 28:651-667.

Juan, M., R.M. Rivero, L. Romero, and J.M. Ruiz. 2005. Evaluation of some nutritional and biochemical indicators in selecting salt-resistant tomato cultivars. Environ. Exp. Bot. 54:193201.

Kjelgren, R., L. Rupp, and D. Kilgren. 2000. Water conservation in urban landscapes. HortScience 35:1037-1040.

Maathuis, F.J.M. and A. Amtmann. 1999. K ${ }^{+}$ nutrition and $\mathrm{Na}^{+}$toxicity: The basis of cellular $\mathrm{K}^{+} / \mathrm{Na}^{+}$ratios. Ann. Bot. (Lond.) 84:123-133.

Marschner, H. 1995. Mineral nutrition of higher plants. 2nd Ed. Academic Press, San Diego, CA.

Martin, P.K. and R.M.D. Koebner. 1995. Sodium and chloride ions contribute synergistically to salt toxicity in wheat. Biol. Plant. 37:265271.

Mills, H.A. and J. Benton Jones, Jr. 1991. Plant analysis handbook II. MicroMacro Publishing, Inc., Athens, GA.

Nau, J. 1997. Tagetes (marigold), p. 763-766. In: Ball, V. (ed.). Ball redbook, Ball Publishing, Batavia, IL.

Pantalone, V.R., W.J. Kenworthy, L.H. Slaughter, and B.R. James. 1997. Chloride tolerance in soybean and perennial Glycine accessions. Euphytica 97:235-239.

Papadopoulos, I. 1987. Effects of residual soil salinity resulting from irrigation with sulphate waters on lettuce. Plant Soil 97:171-177.

Papadopoulos, I. and V.V. Rendig. 1983. Interactive effects of salinity and nitrogen on growth and yield of tomato plants. Plant Soil 73:4757.

Papadopoulos, I., V.V. Rendig, and F.E. Broadbent. 1985. Growth, nutrition and water uptake of tomato plants divided roots growing in differentially salinised soil. Agron. J. 75:676700 .
Reboll, V., M. Cerezo, A. Roig, V. Flors, L. Lapeña, and P. Garcia-Agustín. 2000. Influence of wastewater vs groundwater on young Citrus trees. J. Sci. Food Agr. 80:1441-1496.

Römheld, V. 2000. The chlorosis paradox: $\mathrm{Fe}$ inactivation as a secondary event in chlorotic leaves of grapevine. J. Plant Nutr. 23:16291643.

SAS Institute, Inc. 2001. SAS/STAT software changes and enhancements through release 8.0.2. SAS Institute, Cary, NC.

Suarez, D.L. and J. Simunek. 1997. UNSATCHEM: Unsaturated water and solute transport model with equilibrium and kinetic chemistry. Soil Sci. Soc. Amer. J. 61:16331646.

Troyanos, Y.E., N.A. Hipps, J. Moorby, and G. Kingswell. 2000. The effects of external potassium and magnesium concentrations' on the magnesium and potassium inflow rates and growth of micropropagated cherry rootstocks, 'F.12/1' (Prunus avium L.) and 'Colt' (Prunus avium L.) $\times$ Prunus pseudocerasus L.). Plant Soil 225:73-82.

Valdez-Aguilar, L.A., C.M. Grieve, J. Poss, and M.A. Mellano. 2009a. Hypersensitivity of Ranunculus asiaticus to salinity and alkalinity in irrigation water in sand cultures. HortScience 44:138-144.

Valdez-Aguilar, L.A., C.M. Grieve, and J. Poss. $2009 \mathrm{~b}$. Salinity and alkaline $\mathrm{pH}$ in irrigation water affect marigold plants: I. Growth and shoot dry weight partitioning. HortScience 44:1719-1725.

Wang, D. 2002. Dynamics of soil water and temperatures in above ground sand cultures used for screening plant salt tolerance. Soil Sci. Soc. Amer. J. 66:1484-1491.

Yang, X., V. Römheld, and H. Marschner. 1993. Effect of bicarbonate and root zone temperature on uptake of $\mathrm{Zn}, \mathrm{Fe}, \mathrm{Mn}$ and $\mathrm{Cu}$ by different rice cultivars (Oryza sativa L.) grown in calcareous soil. Plant Soil 155/156: 441-444.

Yermiyahu, U., S. Nir, G. Ben-Hayyim, and U. Kafkafi. 1994. Quantitative competition of calcium with sodium or magnesium for sorption sites on plasma membrane vesicles of melon (Cucumus melo L.) root cells. J. Membr. Biol. 138:55-63. 